\title{
CAREER GUIDANCE AS A FORM OF SELF-DETERMINATION AND LIFE SELF- REALIZATION OF THE YOUTH
}

\author{
ORIENTAÇÃO PROFISSIONAL COMO FORMA DE AUTODETERMINAÇÃO E \\ AUTORREALIZAÇÃO NA VIDA DOS JOVENS
}

\author{
ORIENTACIÓN PROFESIONAL COMO FORMA DE AUTODETERMINACIÓN Y \\ REALIZACIÓN PROPIA DE VIDA DE JÓVENES
}

\author{
Elita S. TABOLOVA ${ }^{1}$ \\ Vladimir A. TARANOV ${ }^{2}$ \\ Natalia A. PEREPELKINA ${ }^{3}$ \\ Tatyana I. LANTSOVA ${ }^{4}$
}

\begin{abstract}
Professional self-determination of young people is a controversial process, complicated by the need to choose the field of activity and determine their place in life. Considering the complex influence of all factors on the professional orientation of young people, a reliable guarantee of the young person's choice of profession as part of life selfdetermination. However, it cannot be assumed that this process does not need management and practical support, and it can be carried out in a self-adjusting way. In addition, when choosing a profession, young people often rely on external attributes (publicity, showiness, prestige of the profession within the immediate circles) which gives rise to a corresponding interest in its development. Sometimes they do not consider their correspondence to the requirements of the professional field: personal traits representing the importance of a professional, intellectual level of development, or the physiological capabilities necessary for the implementation of this professional activity. Increased attention is aimed at the development of the natural instincts of the younger generation, as well as their professional formation, that is, organizing assistance to young people in the choice of employment. At the same time, the choice should be made not only with a focus on the needs and opportunities of young people themselves, but also considering the labor market situation, in the conditions of continuous updating of the list of popular professions. Willingness to respond quickly to market demands is the most approved approach to choosing a profession in modern conditions. Timely and qualified assistance in professional orientation would help young people meet the highest need: the need for self-realization.
\end{abstract}

KEYWORDS: Career guidance. Self-determination. Life self-realization. Prospects. Competitiveness. Education. Self-knowledge.

1 Stavropol State Pedagogical Institute (BRANCH), Zheleznovodsk - Russia. Senior lecturer. ORCID: https://orcid.org/0000-0002-6280-0690. E-mail: elita721@rambler.ru

2 Stavropol State Pedagogical Institute (BRANCH), Zheleznovodsk - Russia. Senior lecturer. ORCID: https://orcid.org/0000-0002-5330-3289. E-mail: wlatar07@mail.ru

3 Stavropol State Pedagogical Institute (BRANCH), Zheleznovodsk - Russia. Senior lecturer. ORCID: https://orcid.org/0000-0002-2509-8783. E-mail: ptiza kmv@mail.ru

4 Stavropol State Pedagogical Institute (BRANCH), Zheleznovodsk - Russia. Senior lecturer. ORCID: https://orcid.org/0000-0003-0325-093X.E-mail: tatiana77994@yandex.ru

RPGE- Revista on line de Política e Gestão Educacional, Araraquara, v. 25, n. esp. 1, p. 726-742, mar. $2021 . \quad$ e-ISSN:1519-9029 DOI: https://doi.org/10.22633/rpge.v25iesp.1.15009 
RESUMO: A autodeterminação profissional dos jovens é um processo controverso, complicado pela necessidade de escolher o campo de atividade e determinar seu lugar na vida. Levar em conta a complexa influência de todos os fatores na orientação profissional dos jovens é considerado uma garantia confiável da escolha da profissão do jovem como parte de sua autodeterminação da vida. Entretanto, não se pode supor que este processo não precise de gerenciamento e apoio prático, e pode ser realizado de forma autoajustável. Além disso, ao escolher uma profissão, os jovens muitas vezes confiam em atributos externos (publicidade, ostentação, prestígio da profissão dentro dos círculos imediatos), o que dá origem a um interesse correspondente em seu desenvolvimento. Às vezes eles não levam em conta sua correspondência com as exigências do campo profissional: características pessoais que representam a importância de um profissional, nível de desenvolvimento intelectual ou as capacidades fisiológicas necessárias para a implementação desta atividade profissional. Uma maior atenção é destinada ao desenvolvimento dos instintos naturais da geração mais jovem, assim como sua formação profissional, ou seja, na organização da assistência aos jovens na escolha de um emprego. Ao mesmo tempo, a escolha deve ser feita não apenas com foco nas necessidades e oportunidades dos próprios jovens, mas também levando em conta a situação do mercado de trabalho nas condições de atualização contínua da lista de profissões populares. A vontade de responder rapidamente às demandas do mercado é a abordagem mais aprovada para escolher uma profissão em condições modernas. Uma assistência oportuna e qualificada, na orientação profissional, ajudaria os jovens a atender à mais alta necessidade: a necessidade de autorrealização.

PALAVRAS-CHAVE: Orientação de carreira. Autodeterminação. Autorrealização na vida. Prospectivas. Competitividade. Educação. Autoconhecimento.

RESUMEN: La autodeterminación de los jóvenes es un proceso controvertido complicado por la necesidad de elegir una esfera de actividad profesional y encontrar su nicho en la vida. La toma en consideración de la influencia integral de la totalidad entera de los factores en la orientación profesional de los jóvenes es una garantía fiable de la elección de carrera como parte de su autodeterminación en la vida. No obstante, no se puede suponer que este proceso sea autoajustable, sin necesidad de control y soporte práctico. Además de eso, muchos jóvenes suelen elegir su carrera por atributos externos, incluyendo publicidad, espectacularidad, valor de prestigio en el círculo ínmediato, la presencia de las cuales genera el interés en aprenderla. Con todo eso, a veces los jóvenes no consideran su cumplimiento con las exigencias para especialistas en una esfera particular, incluyendo rasgos personales de significancia profesional, nivel de desarrollo intelectual y capacidades psíquicas y fisiológicas necesariabl para practicar precisamente la actividad profesional concreta. La sociedad presta una atención creciente al desarrollo integral de talentos naturales de la generación joven así como a su crecimiento profesional, es decir, a la ayuda a los jóvenes con la elección de carrera. En este caso, se debe hacer la elección profesional teniendo en cuenta no solamente las necesidades y aptitudes de los jóvenes propios pero tambien la conyuntura del mercado de trabajo en el contexto de actualizaciones permanentes de la lista de profesiones solicitadas. La disposición para responder rápidamente a los requerimientos del mercado es el enfoque más adoptado a la elección de carrera en la situación moderna. La ayuda oportuna y de alta calidad en la orientación profesional permitirá a los jóvenes a satisfacer su necesidad de realización propia.

PALABRAS CLAVE: Orientación profesional. Autodeterminación. Realización propia en la vida. Perspectivas prometedoras. Competitividad. Educación. Conocimiento de sí mismo. 


\section{Introduction}

The socio-economic life of modern society is characterized by a high degree of specialization of labor and a high level of intensification of social production. In these conditions, the problem of life self-realization is particularly acute and related to the process of choosing subjects and determining a young person's place in life. In the pedagogical theory and practice of education, this phenomenon is called career guidance.

Comprehensive work to assist young people in professional self-determination is an integral part of the educational process. This is essential, since the goal of professional selfdetermination is the need to teach a person to consciously choose a profession and develop the necessary competencies. The choice of profession largely determines the attitude of young people to the labor process and its results, the ability to realize their creative manifestations, and the desire to achieve high performance in labor and social activities. A well-chosen profession is the key to the successful implementation of the life plans of both an individual and society.

Of course, for the best organization of this work, one should take into account all related factors and the real conditions of social production in the country, when the old functional division of labor ceases to exist, and the specialists with a harmonious fusion of mental development, polytechnic education and skills of productive labor become increasingly in demand.

In these conditions, the problem of choosing a profession is solved on the basis of complete individual freedom, which is an indicator of freedom as a social achievement. However, as it is rightly noted by sociologists, this freedom is limited by the fact that 'the hierarchy of occupations is preserved since it depends not only on social factors, but also on the natural inclinations of a person' (CHEREDNICHENKO, 2004).

Professional self-determination is a consistent and step-by-step choice of professional activity that guarantees full self-realization of the individual in specific social conditions. Professional self-determination implies an autonomous and effective position of the individual in the development of the profession, as well as consistent implementation of the strategy of professional self-determination. Personal strategy of professional selfdetermination, as a rule, has a number of components, namely:

A) education and self-education: they imply the accumulation of general knowledge including information about a variety of professions obtained as a result of an energetic and targeted research about the specialties and their features; they narrow the search field and 
specify the plans for the future;

B) self-knowledge: is carried out both in the form of self-knowledge of a person in general (I-image) and in a narrower sense: as a subject of professional self-determination, a person who creates professionally significant traits as the most important ones;

C) self-realization-occurs in the form of direct and inclusive participation in various types of activities, which builds and develops social determination, independence, expanding the range of interests and involuntary search for their business and place (PEREPELKINA, 2018).

The organization of professional self-determination of modern graduates shifts the focus from acquaintance with the world of professions in general to certain options for professional choice. At this point, it is necessary to resolve cognitive issues (reference and information, assistance in self-knowledge, planning, selection), as well as to develop the moral and emotional stability of the optant, which helps to prepare for unplanned difficulties in the process of achieving the professional goal. It is also necessary to assist school graduates in understanding life and professional choices, and create conditions for discussing value, moral, and moral or legal issues that are difficult for the optant.

Unfortunately, today there is no such unified long-term program in Russian education system, and in some cases there are no clear theoretical criteria for developing specially organized career guidance.

First of all, this concerns schools. With the resulting shortage of socially useful work in the system of its educational tools, school education reveals many vulnerabilities and shortcomings including in the professional orientation of students and their preparation for work.

It is clear that according to a systematic, long-term program, it is more reasonable to prevent these shortcomings, which would allow the university to carry out the task better: to prepare a young specialist who has already made the professional choice to work in certain field.

Of course, this does not mean that the university should withdraw itself from the process of preparing applicants and completely transfer these affairs to the shoulders of the school, cooperation with which (together with the corresponding branch of social production) is thought of as a fairly reliable organizational basis for training a young, comprehensively emerging specialist.

It should be borne in mind that this cooperation begins at school, and the participation 
of the university at this stage of educational activity should be reduced not only to conducting individual practical activities with students (organizing clubs, Olympiads, electives), since this can be done by school employees themselves.

The methodological reservations made in this paper are necessary since the literature about career guidance considers this work as a relatively independent, specially organized part of education with its own specific goals and ways of implementation, the conceptual foundations of professional self-determination and pedagogical support. These concepts are found in the works of Blinov V. I., Sergeeva I. S., Zachesova E. V., Esenina E. Yu., Kuznetsova (2015), Zhurkina (2016), Pryazhnikova (2016), Lantsova (2017), Perepelkina (2018), Sal'tseva (s/a), Smirnova (2018), Tabolova (2020), Taranova (2015), Chistyakova (2007), and others.

This paper is to clarify from the very beginning that professional orientation in this sense is an redundant term that does not reveal specific features that go beyond the entire system of education. Moreover, it expresses the system-forming essence of the entire sociopedagogical reality for the formation of a fully developed personality, the only form of formation and implementation of which is its inclusion in professional activities.

Career guidance as a specially organized work arose in the conditions when Russian schools had discovered a deficit of socially useful, productive work, in isolation from which educational practice revealed significant shortcomings in achieving its main goal, which was the reason for its fundamental transformations.

In these conditions, career guidance was understood as a kind of panacea designed to fill in the gaps that had been formed, to carry out its tasks with greater success; the more fully the optimal ways and methods of its implementation were developed, the better was the result.

However, the scientific basis of such work is more pronounced than deduced and implemented in accordance with the increased requirements of modern society, given the existing stereotypes of educational practice.

Zeer (2003), Klimov (1984), and Pryazhnikov (2007) in their works include into such requirements the formation of young people's readiness to adequately respond to the challenges of the new time. The analysis of the works on the problem of professional selfdetermination of young people allows to highlight the specifics of professional selfdetermination in Russia. They are:

- expanding the variability of the professional path;

- non-guaranteed employment; 
- dynamism and uncertainty of structural employment;

- social inequality manifested in the ability of different categories of young people to choose and get certain jobs;

- growth of the optant's personal responsibility for decision-making (ZEER, 2003; KLIMOV, 1984; PRYAZHNIKOV, 2007).

Awareness of these features is increasingly pressing the demand for modern education: 'lifelong learning', put forward by the President of the European Commission, Jacques Delors. The problem, obviously, is not only that the appropriate forms and methods of specially organized career guidance have not yet been found, as a result of which the tasks of choosing a place in life for a young person would have been optimally solved. The fact is that the educational practice itself carried out separately from the systematic socially useful work of schoolchildren needs a qualitative restructuring, and no additional methodological order adjustments can give an educational effect that solves not only the problem of choosing a profession, but also ensures the formation of a whole and integral personality with high moral qualities. After all, it is easy to understand that it is not a commitment to a particular profession that ultimately determines the social value of an individual; it is moral stance, and personal development and mastery of the profession are far from being equal.

It seems, that the optimistic thought that 'general education schools have good conditions for organizing pedagogically sound career guidance' without attracting additional resources and restarting the educational system is not sufficiently justified. What is needed is a reset, a sharp breaking of the modern stereotypes about the existing pedagogical reality. This is the whole point of the ongoing reform of general education and vocational schools, which has direct access to the training the specialists in higher education.

It is interesting that work on career guidance in isolation from the organization of professional activity has to use mainly declarative and illustrative methods and forms of introduction to the profession; the main place is occupied by theoretic activities like 'All work is good, choose one to your taste'.

It includes activities on informing the youth about the professions, professional education, career counseling, and professiongraphy. All this deserves attention, but it cannot replace the participation of children in direct professional activities. It is important not only for the formation of a whole, purposeful personality, but also for solving more narrow tasks of choosing a profession. However, there are a lot of recommendations regarding the actualization of work to solve career guidance problems in research. But, unfortunately, the 
role of labor here is often not emphasized and is mainly reduced to familiarization with professions and other norms of career guidance and generally educational impact on the child.

The method of actualizing work in children's lives, implemented at school, is based on traditional approaches that have proven themselves in a relatively stable socio-economic life. 'Teaching teams,' wrote the Lithuanian psychologist L. A. Yovaysha in the end of the last century, 'should not only comprehensively study their students and their relationships with the environment, but also be able to predict their work qualities, abilities, identify the vocation of the individual, and then orient the person to the appropriate practical activity' (YOVAISHA, 1983).

It is overlooked that optimal prediction of the quality and ability of students to identify the vocation of the individual, to form interests is able in activities only, but not based on bare wishes and confessions of a schoolboy identified by a test or using some other deductive methods. After all, the profession can be chosen based on external, formal, insignificant indicators, based on the fact, for example, how the work of a beauty salon or a computer equipment store was arranged.

Thus, the understanding of career guidance as a specially organized system of educational and upbringing work with its own super-tasks that are being adjusted over (under) the existing pedagogical practice, does not have sufficient justification both at the methodological level and at the level of practical implementation, as well as the thought that its solution would ensure the formation of a fully developed personality with a certain profession.

In the works regarding this problem, the essence of the career guidance is sometimes so wide that it is understood as a general science theory, 'principles, methods and contents of the manual to the development of personality, which is able to optimally use the features of their personality in the professional training or work' (RAZUMOVA, 2014).

After all, it is impossible to assume that educational practice does not aim to guide the development of the individual and that it develops it by some other means: without focusing on the use of the individual's personality in professional training or work.

There is no sufficient reason to rely on the miraculous possibilities of some separate, especially organized work on career guidance, since this hobby leads away from the systematic consideration and solution of the problems of forming a whole and integral personality, which receives its full implementation only in professional activities.

This should be emphasized with the greater insistence that in pedagogy there is an old, good terminology that conveys the system-forming essence of the entire educational theory 
and practice for the formation of a human society, called 'polytechnic vocational education'. The general idea expressed in combining learning with work and practice, as is known, was implemented at different stages of school development with varying degrees of satisfaction, approaching a certain, developed ideal.

Career guidance has just become one of the forms of work that was found during the search as a way to overcome the emerging difficulties and shortcomings in the education of a new person who is engaged in a shortage of socially useful work. It is interesting to note that under these conditions, the schools found themselves in a paradox: while taking up the formation of a complete personality, they still place the main emphasis on the declarativeillustrative method affecting the mind only with theory and neglecting practice.

Currently, when the importance of labor is emphasized as the basis of pedagogical modeling, a new way needs to be rethought and evaluated existing forms and methods of work with regard to their role and place in this holistic educational process. It should include the care of the most favorable option of professional self-determination, namely, the youth selecting its own way and vocation.

Today, professional self-determination is considered as a multi-faceted dynamic process of forming a system of basic attitudes to the profession and work, creating appropriate professional intentions and plans, and creating a real image of a professional. The relevance of this issue does not decrease when young people leave the level of leneral education and go to the vocational education system. Often in modern reality, school graduates choose a profession and an educational institution according to its prestige, a money factor ('decent wages in the future') and a determinant of the exclusivity of the profession ('there are few specialists in this field').

The solution to the problem of professional self-determination of students today is seen as an indispensable efficiency of educational organizations in general, and a successful start in the implementation of the chosen profession of young professionals. The success of solving this problem depends not only on the acquired academic knowledge in the studied subjects of the curriculum, but also on the acquired practical competencies.

\section{Materials and methods}

That is why it is necessary to have and implement specially developed programs for professional self-determination of students, which would include professionally saturated practice from the first year at the university, well-planned and linked to the acquired practical 
skills, independent work of students, training sessions, business and role-playing games, as well as other interactive forms of work. It other words, it is everything that contributes to the mastery of general professional and professional competencies (DUSHKOV; KOROLEV; SMIRNOV, 2009).

Many psychological problems may be resolved by diagnosis and prediction of the features of the forming and developing self-determination in adolescence: the awareness of young men and women of various facets of their personality; the formation of the ability to build a picture of the world and use their personal achievements in the field of education to determine their own position and its implementation in conditions of uncertainty; building effective communication with others; a worthy presentation of themselves in new life situations.

It is important to note that the process of professional development of an individual does not always end with the selection of a specific profession. Professional selfdetermination is only possible if young people are involved in professional activity and realize themselves in it.

Currently, when the importance of labor is emphasized as the basis of pedagogical modeling, a new way needs to be rethought and evaluated existing forms and methods of work regarding their role and place in this holistic educational process including the care of the most favorable option of professional self-determination- one's own way and vocation.

One of the priority tasks of the pedagogical process in the university is to make the future profession attractive to students, to increase their passion for the profession and instill love for it, in other words, to make every effort to ensure that the graduate remains in the profession.

It seems that from this point of view, career guidance as a term should be thought of as work on professional and labor support for students, the organization of their productive work, supplemented by mutually coordinated educational and educational activities, the organic unity of which is designed to give the greatest effect

Career guidance is one of the leading directions in the work of the teaching staff of the Branch of the state budgetary educational institution of higher education 'Stavropol state pedagogical institute' in Zheleznovodsk.

The goals of career guidance of the university are as follows:

1) organization of systematic career guidance activities in general education organizations of the Stavropol territory to attract the most trained and professionally oriented applicants;

RPGE-Revista on line de Política e Gestão Educacional, Araraquara, v. 25, n. esp. 1, p. 726-742, mar. 2021. e-ISSN:1519-9029 
2) creating conditions for the most effective socio-psychological support for professional self-determination and self-realization of students, which contributes to building a hierarchy of life meanings that are focused on social values, as well as personal and professional growth.

A project for applicants in 2020 'Crossroads of seven roads' is being implemented on the premises of the Zheleznovodsk branch of Stavropol state pedagogical institute. The project is organized by the enrolment board and departments of the institute. The project is designed to increase the importance and prestige of the teacher's profession, its social and professional status, as well as to promote information about the branch of the Stavropol state pedagogical institute in Zheleznovodsk and attract applicants to its faculties and specialties.

The project includes:

1) regional essay contest for students of years 9 and 11 'My profession is my future' (January-February 2020);

2) workshop for parents of 9th and 11th year graduates 'I can convince my child to study' (February 2020);

3) regional student photo contest 'Expected teacher'

4) training course for applicants 'School knowledge for life' (February 2020);

5) regional students photo contest 'Happy Childhood' $\underline{6}$ in the form of a remote task (March 2020);

6) professional testing of applicants (March 2020);

7) business game 'I know how to make my choice' (April 2020);

8) regional presentation competition among students of years 9 and 11 'The world of my hobbies' (April 2020);

9) quiz among students of years 9 and 11 'Pedagogical heritage of Maria Montessori' (may 2020);

10) joint event in the form of a business game for parents and future applicants 'I Want + I Can = the Right choice' (May and June 2020);

5 Available:

http://sgpizh.ru/source/AllCategory/Abiturientam/Perekrestok_semi_dorog/polozenie_o_fotokonkurse.pdf. Access: 10 dec. 2020.

${ }^{6}$ Available:

http://sgpizh.ru/source/AllCategory/Abiturientam/Perekrestok_semi_dorog/polojenie_schastlivoe_detstvo.pdf. Access: 10 dec. 2020. 
11) video contest 'I choose SSPI!" among students of grades 9 and 11 and students of the Zheleznovodsk branch of Stavropol state pedagogical institute (May 2020).

The project 'Crossroads of seven roads' is intended for children who study in state, municipal and private educational organizations that implement general education programs in the Russian Federation including children with disabilities.

Due to the threat of a new coronavirus infection in the spring of 2020 and in order to reduce the possibility of Covid-19 spreading, some of the activities were carried out remotely.

\section{Results}

The need to make a choice of profession is associated with the fact that young people experience significant difficulties related to the awareness of responsibility for their choice.

A truly successful choice is accompanied by social and moral experiences, namely, understanding the meaning of life, one's place in it, as well as the nature of one's own 'I'.

Profession characterizes the technological side of a certain type of work that requires appropriate psychophysiological qualities and abilities without focusing on other social and moral attributes of an individual.

It is possible to teach a child to labor,' remarks I. S. Kon, one of the founders of the modern Russian school of sociology, a popularizer of science and educator, 'and help him choose a profession; however, without proper moral and ethical qualities, they would quickly learn to do well only profitable work avoiding the unprofitable one (KON, 1978).

For almost a century of its history, the branch of SSPI in Zheleznovodsk has been and remains an important center of education, science and innovation. It includes the training of highly qualified, competitive specialists in the organization of basic professional educational programs, taking into account global trends in science and education that meet the requirements of the state and society and contribute to the growth of the intellectual resource of the Stavropol territory and Russia. Every year students of the branch participate in professional skill championships: World Skills Russia in categories 'Preschool education'; 'Abilimpix' in category 'Primary school teacher'; 'Teacher of the year'. They also take prizes.

The branch has an active student teaching group 'Danko' and a student volunteer group 'Luchik'. Every year students of the branch participate in the North Caucasus youth forum 'Mashuk' and receive grant support for the implementation of their projects. 


\section{Discussion}

It is no coincidence that in the most difficult periods of our national history, the authorities have always turned to the teacher as the main guardian and distributor of spiritual traditions, knowledge about the processes of personality formation and human potential management. The teacher's profession, where the moral law is an enduring value, allows young people to acquire and preserve all the best human qualities in the learning process in order to realize themselves in society and be in demand in any life situations (RED'KO, 2016).

Youth is the time when people make the most important decisions that determine who to be, with whom to be, and how to be. The branch of SSPI in Zheleznovodsk successfully copes with the task of organizing a new set: it cooperates with the community of teachers of the region, the parent community, trying to arouse interest and attract not only academically prepared, but in every sense the best graduates to teaching. This approach to the selection of applicants clearly justifies itself: almost half of the branch's graduates have degrees with distinction, and two-thirds of working undergraduates get their first professional practical experience in educational institutions.

A change in the ideology of career guidance is typical for modern society. Today the traditionl for national education system focus on recruitment for existing jobs is replaced with the selection of profession for a person.

These circumstances make it necessary to help young people in their quest for selfdetermination and self-realization, which would help them successfully navigate the diversity of professions while relying on their own individual characteristics and capabilities. In the context of educational organizations, this mission is performed by social and psychological services.

The task of a university as a 'forge' of scientific personnel is to develop a methodology for organizing career guidance on the appropriate profile of university training, which is embedded in the educational process of the school at all stages of its work with children.

In order to prevent departmental isolation caused by the presence of a fairly narrow range of university interests and unpromising approach to vocational education in general education associated 'with a focus on the needs of the nearest production', we need a single, coherent system of professional orientation to provide the set of specific tasks for all services participating in specialist training.

At the same time, it should be borne in mind that a systematic approach to the analysis of any form of human activity requires the inclusion of this object (in this case, career guidance) in a broader whole as part of it. 
This is necessary because of a socio-pedagogical category of career guidance, since like any social category, it has its own prerequisites, and as a system shows a tendency to develop in the direction of integrity. It is clear that taking into account these features is a prerequisite for developing sound decisions and recommendations.

Effective professional orientation requires the development of coherent strategies and evidence-based programs that involves consideration of problems in the whole system ('preschool period - school - university - production'), with all its layers (courses, teaching classes, small universities), with a clear division of labor all services to ensure continuity of stages of formation of professional identity.

Pedagogical universities are special due to the future professional activity of their graduates, since the profession of a teacher requires both a decent basic training and a vocation. Of course, the vast majority of applicants to pedagogical universities know the features of pedagogical activity. Therefore, the need to have a broad outlook, a rich vocabulary, deep knowledge of academic disciplines, and the most important is the personal traits necessary for being a teacher. At the same time, there are many first-year students who do not see themselves as a teacher in the future and do not even allow themselves to think about working at school. Often, while studying at a University, they work in various areas of urban infrastructure that are not related to teaching activities (ILLARIONOV; ILLARIONOVA, 2015).

\section{Conclusion}

Unfortunately, today the teacher's profession in Russia is not prestigious. Only those who have devoted their lives to teaching can refute this judgment. 'I give my heart to children' - this is how V. A. Sukhomlinsky, who had worked at the school for more than three decades, called his book. This beautiful metaphor expresses the essence of pedagogical activity if it becomes a vocation (SHUMSKAYA, 2018).

Thus, professional self-determination acts as a conscious and independent sociopsychological and deterministic process of personality formation.

The most significant aspects of the formation of professional self-determination of a young person studying in high school should include:

1) professional information and professional education (providing information about the needs of the labor market of the city, region, and country in certain human resources; requirements for personal and professional qualities of applicants; ways to acquire these 
qualities; socio-economic, psychological and physiological specifics of a particular profession);

2) development of abilities, interests, and aptitudes in activities that are close to professional;

3) providing professional advice (organization of individual assistance to students in grades 9 and 11 in choosing the intended professional activity that would meet the individual interests and inclinations of the optant, would meet the human resource needs of the labor market in competent and competitive specialists, in specifying employment prospects and finding suitable educational institutions);

4) a well-built system of professional selection (a well-organized procedure for diagnostics and evaluation of the optant's capabilities in mastering the profession, achieving the necessary level of professional skill and successfully implementing the range of responsibilities provided for by the profession in standard and complicated conditions);

5) professional adaptation (the process of entering a profession, mastering basic professional competencies in the chosen specialty) (PEREPELKINA, 2018).

The significance of the teacher's role in the progressive development of society was determined by the Soviet and Russian philologist, culturologist, art critic, doctor of philology Dmitry Likhachev: 'Teaching is an art, a work no less creative than the work of a writer or composer, but more difficult and responsible. The teacher directly addresses the human soul. He educates with his personality, his knowledge and love, his attitude to the world...'.

This is why it is so important to restore the prestige of teacher's profession: because the model of the future society depends on teachers and how they teach and educate their students.

\section{REFERENCES}

BLINOV, V. I. et al. Kontseptsiya soprovozhdeniya professional'nogo samoopredeleniya obuchayushchikhsya $v$ usloviyakh nepreryvnosti obrazovaniya [The concept of supporting professional self-determination of students in the conditions of continuous education]. Moscow: FIRO, 2015.

CHEREDNICHENKO, G. A. Molodozh' Rossii: sotsial'nyye oriyentatsii i zhiznennyye puti (opyt sotsiologicheskogo issledovaniya) [Youth of Russia: social orientations and life paths (experience of sociological research)]. Saint Petersburg: Izdatel'stvo Russkogo Khristianskogo gumanitarnogo institute, 2004. 
CHISTYAKOVA, S. N. Pedagogicheskoe soprovozhdenie samoopredeleniya shkol'nikov: metod. posobie [Pedagogical support of students' self-determination: study guide]. Moscow: Izdatel'skiy tsentr "Akademiya”, 2007.

DUSHKOV, B. A.; KOROLEV, A. V.; SMIRNOV, B. A. Psikhologiya truda, professional'noy, informatsionnoy i organizatsionnoy deyatel'nosti [Psychology of labor, professional, informational and organizational activity]. Moscow: Slovar, 2009.

ILLARIONOV, S. V.; ILLARIONOVA, L. P. Plyusy i minusy obucheniya s primeneniyem distantsionnykh obrazovatel'nykh tekhnologiy [Pros and cons of training with the use of distance educational technologies]. TSITISE, n. 2, p. 27, 2015.

KLIMOV, E. A. Psikhologiya professional'nogo samoopredeleniya [Psychology of professional self-determination]. Rostov-on-Don, 1984.

KON, I. S. Otkritiye Ya [The opening of I]. Moscow, 1978.

LANTSOVA, T. I. Primenenie sovremennykh pedagogicheskikh tekhnologiy v protsesse diagnostiki i razvitiya sposobnosti k gipotetichnosti budushchego pedagoga-psikhologa [Application of modern pedagogical technologies in the process of diagnostics and development of the ability to hypothetical future teacher-psychologist]. Molodoy uchenyy, $\mathrm{n}$. 3-1 (137), p. 12-15, 2017.

MITINA, L. M. Professional'noe i lichnostnoe samoopredelenie molodezhi: vchera, segodnya, zavtra [Professional and personal self-determination of youth: yesterday, today, tomorrow]. In: ALL-RUSIAN RESEARCH AND PRACTICE CONFERENCE, 2008, SAMARA. Proceedings [...]. Samara: Samarskaya gumanitarnaya akademiya, 2008.

PEREPELKINA, N. A. Professional'noe samoopredelenie starsheklassnikov kak vozmozhnost' realizatsii konkurentnosposobnoy lichnosti v real'nykh rynochnykh usloviyakh sovremennogo rossiyskogo gosudarstva [Professional self-determination of high school students as an opportunity to realize a competitive personality in real market conditions of the modern Russian state]. In: INTERNATIONAL SCIENTIFIC AND PRACTICAL CONFERENCE, 2018. Proceedings [...]. 2018.

PILYUGINA, E. I. Tekhnologii adaptatsionnoy integratsii lichnosti studenta-migranta $\mathbf{v}$ polikul'turnuyu sredu vuza [Technologies of adaptive integration of the personality of a migrant student in the multicultural environment of the university]. In: Collected articles of the International scientific and methodological competition. In 2 parts. 2020.

PRYAZHNIKOV, N. S. Aktiviziruyushchaya profkonsul'tatsiya [Activating career guidance]. Moscow: "Akademiya", 2014.

PRYAZHNIKOV, N. S. Professional'noe samoopredelenie: teoriya i praktika [Professional self-determination: theory and practice]. Moscow: "Akademiya", 2007.

PRYAZHNIKOV, N. S. Proforietologiya [Proforientology]. Moscow: Yurayt, 2016. 
RAZUMOVA, M. V. K voprosu o traktovke ponyatiya 'Proforiyentatsiya' [On the question of the interpretation of the concept of career guidance]. Professional'noe obrazovanie $\mathbf{i}$ obshchestvo, v. 1, n. 9, p. 51-59, 2014

RED'KO, L. L. Gotovit' novogo uchitelya dlya novoy Rossii [Prepare a new teacher for the new Russia]. Vestnik Stavropol'skogo gosudarstvennogo pedagogicheskogo institute, $p$. 13-25, 2016.

\section{SALTSEVA, S. V., YARTSEV, M. Dosugovaya deyatel'nost' i professional'noe} stanovlenie pedagoga: ucheb. posobie [Leisure activities and professional formation of a teacher: study guide]. Ministry of education and science of Russian Federation. Orenburg region Institute for advanced training of education workers, state educational institution Orenburg State Pedagogical University. Orenburg: Izd-vo OPCRA.

SHUMSKAYA, O. A. Kakim dolzhen byt' sovremennyy uchitel'? [What should a modern teacher be like?]. In: INTERNATIONAL SCIENTIFIC CONFERENCE, 5., 2018. Proceedings [...]. Krasnodar: Novatsiya, 2018.

SMIRNOVA, G. M.; UDARTSEVA, S. M.; GOTTING, V. V.; SHEBALINA, O. A. Professional'naya oriyentatsiya molodezhi v sovremennykh usloviyakh [Professional orientation of youth in modern conditions]. Novosibirsk: Izd. ANS "SibAK”, 2017.

TABOLOVA, E. S.; DONEVA, O. V. Metody matematicheskoy statistiki v podgotovke budushchikh psikhologov i pedagogov [Methods of mathematical statistics in the preparation of future psychologists and teachers]. Voprosy pedagogiki, n. 2-1, p. 63-66, 2020.

TARANOV, V. A. Organizatsiya dukhovno-nravstvennogo vospitaniya molodozhi v usloviyakh sovremennogo pedagogicheskogo vuza [Organization of spiritual and moral education of youth in the conditions of a modern pedagogical university]. Sovremennaya nauka: aktual'nye problemy i puti ikh resheniya, v. 5, n. 18, p. 109-111, 2015.

YOVAISHA, L. A. Problemy professional'noy oriyentatsii shkol'nikov [Problems of professional orientation of school children]. Moscow: Pedagogika, 1983.

ZEER, E. F. Psikhologiya professiy: Uchebnoe posobie dlya studentov vuzov [Psychology of professions: coursebook for university students]. 2. ed. rev. and ext. Moscow: Akademicheskiy Proekt; Ekaterinburg: Delovaya kniga, 2003.

ZHURKINA, A. Y. A; SERGUSHIN, E. G.; SERGUSHINA, O. V. Teoreticheskie aspekty formirovaniya sotsial'no-professional'nogo samoopredeleniya uchashchikhsya obrazovatel'nykh organizatsiy [Theoretical aspects of formation of social and professional self-determination of students of educational organizations]. Integratsiya obrazovaniya, v. 20, n. 1, p. 29-36, 2016. 


\section{How to reference this article}

TABOLOVA, E. S.; TARANOV, V. A.; PEREPELKINA, N. A.; LANTSOVA, T. I. Career guidance as a form of self-determination and life self-realization of the youth. Revista on line de Política e Gestão Educacional, Araraquara, v. 25, n. esp. 1, p. 726-742, mar. 2021. eISSN:1519-9029. DOI: https://doi.org/10.22633/rpge.v25iesp.1.15009

Submitted: 06/11/2020

Required revisions: 18/01/2021

Approved: $23 / 02 / 221$

Published: 01/03/2021 